\title{
Development of Maritime Village-Based Strategy: A Case Study of Tambak Lorok Maritime Village in Semarang, Indonesia
}

\author{
Putut Cahyo Nugroho ${ }^{1 *}$, Maryono ${ }^{1,2,4}$, and Fajrul Falakh ${ }^{3}$ \\ ${ }^{1}$ Master of Environmental Science, School of Postgraduate Studies, Diponegoro University, \\ Semarang, Indonesia \\ ${ }^{2}$ Department of Urban and Regional Planning, Faculty of Engineering, Diponegoro University, \\ Semarang, Indonesia \\ ${ }^{3}$ Department of Biology, Faculty of Science and Technology, Universitas Islam Negeri Walisongo \\ Semarang, Indonesia \\ ${ }^{4}$ Center for Green Infrastructure Resilience Development, School of Postgraduate Studies, \\ Diponegoro University, Semarang, Indonesia
}

\begin{abstract}
Tambak Lorok is an area that including in Community-Based Planning in Semarang which had through various processes, starting from the preparation process to the participatory planning stage. To get the desired environmental quality, this area design approach was carried out within the scope of urban planning known as urban design. This research was conducted to analyze the development strategy design based on the current condition of Tambak Lorok village. The research design carried out in this study was observational with the support of a qualitative approach. The data was resulted by direct and in-depth interviews. The process was intended to find out how did the needs and desires of the community and other stakeholders in addressing the arrangement and development of the research area. The conclusions were obtained from the study of implementation of the maritime village in Tambak Lorok were still not fully realized, this was due to the many difficulties and obstacles that caused progress to be unsustainable. For example, the plan did not work effectively because it only involves part of the community, so the community refused at the beginning of the work.
\end{abstract}

\section{Introduction}

Tambak Lorok is an area that is included in Community-Based Planning in Semarang City, which has gone through various processes, from the preparation process to the participatory planning stage. The environmental planning plan for Tambak Lorok Village in a macro or comprehensive manner contains identified areas based on various criteria for problems and potential arrangement of areas in the Tambak Lorok village. In this area, it is made the main priority over intervening through community agreement physically. The process of designing physical elements in the construction of environmental facilities is carried out by

* Corresponding author: putut.cahyo.nhoegroho@gmail.com 
various interested parties and based on the needs of each of these parties so that a variety of physical forms emerge. Tambak Lorok village is also intended for ecotourism by prioritizing aspects of local wisdom of the city of Semarang; the local government calls this Tambak Lorok village the "Kampung Bahari", as the name for ecotourism branding. [1]. To obtain the desired environmental quality, an area design approach is carried out, which is known as urban design within the scope of urban planning.

Semarang City is an area formed from alluvial deposits that are still relatively young, allowing for compaction, which can cause the phenomenon of land subsidence. Groundwater abstraction also contributes to this phenomenon. Therefore land subsidence in North Semarang is quite significant, namely $8.23 \pm 1.58 \mathrm{~cm} /$ year [2]. The frequent tidal floods that occur every year in Tambak Lorok village correlate with land subsidence.

In 2013, the population in Tambak Lorok village reached 9,503 people. Most Tambak Lorok residents have livelihoods as fishermen, traders, small industries, home industries related to fishing. Fishers are still classified as traditional fishermen because they use simple tools and are very dependent on the weather, so anglers often do not get income because they do not go to sea [3]. The majority of the population living in Tambak Lorok village makes a living by utilizing the produce sea, do not fully benefit from living on the coast. Until 2015, the condition of this village was quite a slum. In addition to the loss of mangrove forests, there is a lot of industrial waste from around the area and garbage from various areas in the city of Semarang, which empties into the local river. Make fish or sea animals die. Not only built-in garbage, but garbage from residents also pollutes the sea around the Tambak Lorok village. This condition causes the income of fishers to be low so that it is not sufficient for their daily needs.

Public involvement can force the government to explore management issues, concerns, and actions from multiple perspectives and gather multiple views and information. In theory (and in many cases, practice), governments are encouraged to pursue policies that are more equitable, socially relevant, and environmentally friendly [4-5]. Although environmental policy-making to manage coastal areas and fishing communities want an efficient and straightforward process, deep-rooted differences in motivation can hinder meaningful communication. These differences are often exacerbated in government systems designed to limit social interactions and are influenced by the power of capital. This makes the formulation of environmental policies very highly complex and requires joint enforcement, both government and local communities [6].

The Governments must balance attitudes, preferences, and behaviours as stakeholders to improve compliance and efficiency of their management decisions to the wider community [7] and combine the best available science on using resources at their disposal. Sustainable, this is useful to explain the feasibility of a political decision. Lack of information on easy methods to identify sustainable resource allocations makes it difficult for stakeholders to make effective and inclusive decisions. The conflicting goals and disagreements about how increasing scientific uncertainty should be considered in the context of different public values demand a more nuanced consideration of how involvement in resource decision making can and should be handled [8].

Innovation is an essential part of environmental policy, and driving innovation is often an explicit goal of policymakers. The planning of the maritime village area in the preliminary study implies that the community's life in the Tambak Lorok area must characterize marine (maritime). Two main things underlie the planning concept of Tambak Lorok Village, namely the morphology that shapes the area and economic factors. The morphology of the area is currently formed irregularly and is a residential area that grows unplanned. Meanwhile, it characterizes a poor, dirty and slum area (slum area) from an economic aspect. Therefore, in area planning, the concept of area planning is emphasized 
on 3 (three) keywords: Urban community, unique settlements, and a seafront landscaping scheme.

This paper updates the review regarding the pattern of policies that the Semarang city government has taken to address the Tambak Lorok village case. The purpose of this study is to determine the government's policy efforts to maintain Tambak Lorok fishing village and how the concept of "Maritime Village" is a sustainable development effort in floodprone coastal areas. This knowledge is important because Tambak Lorok "Kampung Bahari" can be a model maritime village. Fishers who can survive and be sustainable despite being in a coastal area that is prone to flooding and experiencing land subsidence significantly.

\section{Research Method}

The research design conducted in this research is observational with the support of qualitative approaches. This research was conducted to design a development strategy based on the current conditions of the Tambak Lorok village. This research and field observations were carried out over a long period considering that the author is part of the policy implementer, starting from mid-2015 to the end of April 2019, which includes 3 (three) stages, namely library research, field research (survey) and institutional research. In this study, one of the analytical techniques used is descriptive qualitative analysis techniques. Descriptive-qualitative analysis, namely research that seeks to describe, record, analyze and interpret the spatial planning and utilization patterns in the Tambak Lorok area [9].

Data obtained through direct and in-depth interviews are intended to see the extent of the needs and desires of the community and other stakeholders in responding to the arrangement and development of the research area. Primary data was collected through a direct survey to Tambak Lorok in 2015 by documenting the condition of the village at that time and interviewing the figures Public. Secondary data is library data collected through published research results, online news about the current development of Tambak Lorok, and government regulations related to housing and settlements in coastal areas. The combination of primary data and secondary data is compiled to provide an objective explanation regarding the development of Kampung Bahari as an effort to sustainable development in Tambak Lorok fishing settlement, Semarang city.

\section{Result and Discussion}

\subsection{Overview of the Tambak Lorok Maritime Village}

Tambak Lorok Maritime Village is a fishing village located on the coastline of the Java Sea. The main function of Tambak Lorok village is as a residential area, fishponds and a special trade-in marine product. Tambak Lorok Village is located in Tanjung Mas Village in North Semarang District. Kampung Tambak Lorok is located near the area that connects the main functions of the city of Semarang, such as the port area (Tanjung Emas Port), warehouses, the old city centre, Tawang Train Station and residential centres. The existence of a coastal area has a strategic meaning. One of the development priorities in the coastal area is the improvement of coastal settlements.

Tambak Lorok Village is located in the area of Tanjungmas Village, North Semarang District. Tambak Lorok is one of the coastal villages in Semarang City, located on the banks of the East Canal Flood River and Banger River, which has a total area of 46.8 hectares with an average height of o, 5 meters above sea level. Tambak Lorok has land 
subsidence of 9-10 cm per year. Land use is divided into settlements of 32.4 ha, the port area of 3.2 ha, use of ponds/ponds 11.2 ha and Tambak Lorok has land subsidence of 9-10 $\mathrm{cm}$ per year.

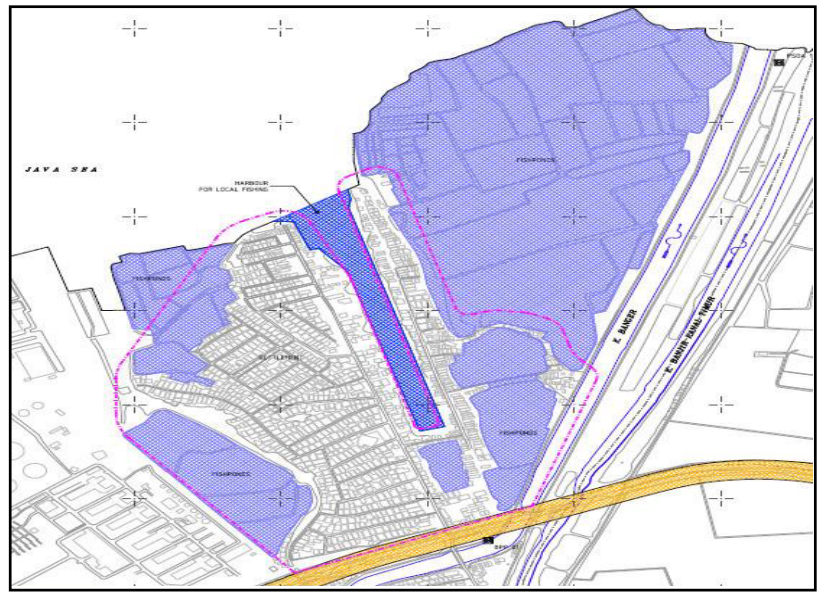

Fig. 1. Tambak Lorok Administrative Region.

As fishermen's settlements, the people who live in the Tambak Lorok area depend on Natural Resources (natural resources), in this case, the sea as a place to find fish, rivers and estuaries as a place to moor boats and the boats in and out of the sea. This life has been integrated with the culture of the community and has been going on for generations. The main potential of the Tambak Lorok area is the presence of a Fish Landing Base (PPI), which includes a Fish Auction Place (TPI). Over time, this village developed as a village with high density. Currently, this village is experiencing a decline in environmental quality. Environmental problems in the form of floods, tides, land subsidence and seawater intrusion are fundamental problems. The accumulated garbage causes the area to become slum and unsanitary. The economic level of the population is low, causing people to experience difficulties in improving their environment.

In 2016, the total population in Tambak Lorok was 30,678 people divided into 5 RWs, namely RW 12 to RW 16 . Of the total population, 30,675 were Indonesian citizens (consisting of 14,424 men and 16,251 women), and three residents were foreign citizens (consisting of 1 male and two female). Located in the area around the port, Tambak Lorok village is included in the slum areas with a density of $>750$ people/ha. It has several lowincome families reaching 970 families. Tambak Lorok contributes $36.02 \%$ to poverty in Tanjung Mas Village, of which the 970 low-income families, the number of families $\leq 3$ in 595 families, the dependents $\geq 4$ are 358 families and the dependents $\geq 8$ are 16 families.

Several problems have caused the Tambak Lorok fishermen village to experience degradation and become a slum, such as:

1. Flooding every year caused by land subsidence and inadequate drainage;

2. fishermen have difficulty going to sea and mooring their boats due to silting of the mouth of the Old East Flood Canal River;

3. Low income level of fishermen so that they are unable to repair their houses which are getting low and unfit for habitation.

Based on the results of interviews and researcher analysis, it is known that Tambak Lorok Village is a residential area located in a coastal area and many residents in the Tambak Lorok area work as fishermen and fish processing centres. Fish processing and trading production centres located around fishing ports can also be used as the main 
economic driver in the Minapolitan area. The Minapolitan National Program raises the concept of area-based marine and fisheries development with the following structure:

1. Region-based marine and fisheries economy: Indonesia is divided into sub-regions for economic development based on natural resource potential, infrastructure and geography.

2. Minapolitan Leading Economic Zone: Each province and regency / city is divided into several leading economic areas called Minapolitan.

3. Production Centers: Each Minapolitan area consists of production and trading centers for marine and fishery commodities and other related activities.

4. Production unit / business: each production center consists of production units or productive fishery business actors.

The objectives of the development of the marine and fisheries sector with the minapolitan concept are as follows:

1. Increase production, productivity and quality

2. Increase the income of fishermen, cultivators and fish processors that are fair and equitable

3. Developing Minapolitan Regions as centers of economic growth in the regions and fisheries production centers as a driving force for the people's economy.

From the analysis results previously described, it can be understood that the Tambak Lorok area is a village in a coastal area; of course, economic activity is closely related to fishing. Some of Tambak Lorok are still working as fishermen, although it has decreased a lot. Fishers in Tambak Lorok usually go to the sea during certain seasons, catching mostly shrimp and squid. Due to several operational constraints, some people have started to switch to other economic activities.

The constraints faced by fishermen are the high operational costs, while the catch is uncertain. Apart from being fishermen, people in Tambak Lorok have several other alternative jobs, namely working as factory workers, traders, tailors and convectors, and processing seafood, including making shrimp paste and presto milkfish. Of course, all forms of business run by several Tambak Lorok residents have different incomes of business. Little by little, they are increasingly developing in running their business, although some still hope that their business will be even more advanced with their resources. Shrimp, squid, and presto milkfish are their superior sources, are expected to reach beyond the Tambak Lorok area.

\subsection{Structuring Strategy and Development of Tambak Lorok Area to become Maritime Village}

The arrangement of Tambak Lorok Village has several concepts that are proposed to become a marine tourism village. Currently, there is a concept and zoning division for the plan to develop a marine tourism village. The concept is to organize the area based on the close relationship between the function of marine settlements as the main zone with the marine industry, tourism and ecological buffer areas. In addition, it is reconstructing the regional structure pattern based on the engineering of fishing boat shipping lines and various protection measures against the threat of flooding. This development also applies a specific theme to the area, which is considered appropriate as a generator of regional activity. The following is an illustration of the development zones of a marine tourism village.

Based on (Fig. 2) below, the development of the Tambak Lorok Area as a marine tourism village can be grouped into several zones, where each zone has its function or concept. The government has appointed six to turn the pond into a maritime village:

1. Settlement Zone 
2. Vertical Settlement Zone

3. Trade Zone

4. Marine and Culinary Tourism Zone

5. People's Harbor and Maritime Industry Zone

6. Commercial Zone

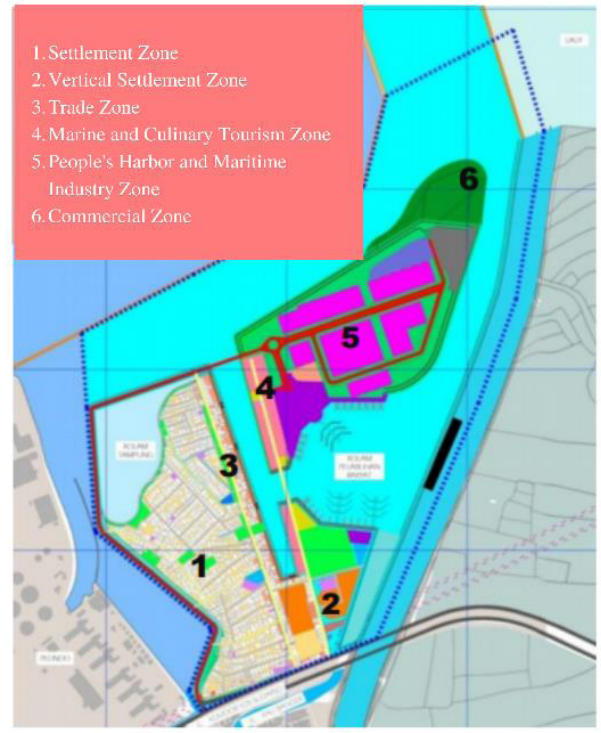

Fig. 2. Maritime Tourism Village Zones in Tambak Lorok, Semarang City, Indonesia.

Maritime Village is not merely a clean coastal village area with adequate infrastructure but a coastal area that also requires social and cultural instruments capable of supporting Tambak Lorok as a complete coastal village tourism destination. In this context, we should be proud that the social capital in the form of a cooperation system and social institutions in the region is still very strong. Many rituals and traditions allow it to become an attraction as a Maritime Village amid modernization and industrialization in the Tambak Lorok area. At this level, the development of Kampung Bahari requires two approaches at once, namely infrastructure and community empowerment. The only results-oriented project paradigm cannot be put forward in building Kampung Bahari. Tambak Lorok residents must be involved thoroughly because they are the ones who will become the real activists of Maritime Village.

In the development of the Tambak Lorok maritime village, a collaboration between stakeholders is needed. This multi-stakeholder activity requires good coordination so that all elements can work together to achieve the expected goals. The limited space for local government to move requires public and private sector assistance to achieve these expectations. The division of tasks is arranged in such a way so that there are no overlapping activities. Local governments are engaged in the aspects of technical planning, budgeting, and implementation of development. The private sector is actively involved in the preparation of designs, physical construction, and maintenance, while residents must create a sense of awareness and actively care for development results. Tambak Lorok is currently under construction towards a maritime tourism village. To make this happen, of course, you must have a plan to build in the area.

By the results of interviews with the implementation of the Kotaku program and the community, there must be communication and community empowerment to succeed in the program. The community empowerment process must start from involvement (participation) in development planning consistently and substantially (not just a formality). 
Especially in the process of implementation, monitoring and evaluation so that the development products produced are not products that are far from the people's needs. Superior Products Community empowerment is also important in building and increasing community expertise in a Maritime Village tourism design.

Environmental issues are an international issue that is being discussed, especially in the era of globalization; all countries are required to use resources wisely to preserve natural resources for humanity in the future. Changes in natural ecosystem processes will affect the role of ecosystem services. Environmental policies related to the implementation of Tambak Lorok as a maritime village area must emphasize aspects of development that are in line with sustainable development; this is useful to reduce the potential hazards that arise in future implementation [9].

\subsection{The Impact of the Kampung Bahari Area on the Tambak Lorok Community}

Slum settlement areas are currently mushrooming in several areas, especially in coastal areas. The coastal paradigm has a high poverty rate. Poverty is defined as the inability of the financial side to meet primary basic needs. Underprivileged conditions have various forms, such as inadequate income, hunger, level of health, limited education, level of environmental cleanliness and inadequate housing conditions. High population density impacts the density of residential areas, which has the potential for the emergence of slum pockets. Slum settlements are a condition of a residential environment in which the physical conditions are not suitable for habitation, all facilities and infrastructure are still not available, have a limited area, are high in density, are prone to social and environmental diseases and endanger the survival of the inhabitants [10].

Slum settlements are synonymous with illegal settlements, namely people who live on land or in cities without permits. Settlements exist because of life, and the purpose of settlements is to create new generations by making infrastructure improvements. The maritime village of Tambak Lorok, from the analysis of the perceptions of researchers from the explanations and statements of the Tambak Lorok area community, several aspects will be felt directly by the community in the Tambak Lorok area, including occupancy density, road damage, waste problems, sanitation, social conflicts, and inter-sectoral conflicts.

\section{Conclusion}

The conclusion obtained from the study regarding the implementation of the maritime village in Tambak Lorok is that it is still not fully realized; this is due to the many obstacles and obstacles that cause progress to be unsustainable. For example, planning was ineffective because it had not fully involved the community so that at the beginning of the work, the community had rejected it. The problem that then develops is that the management of the potential of the marine area has not been matched by a management system that can maintain the balance of the marine ecosystem. This is because, in its development, various problems occur. After all, the management of the Tambak Lorok coastal area with fishing activities, seaweed cultivation and tourism also affects the preservation of the ecosystem under the sea. The impacts that interviews and site observations will feel are housing, road damage, waste, sanitation, social and inter-sectoral conflicts.

\section{References}


1. Susanto, Novie, et al, Development of Ecotourism-Based Strategy: A Case Study of Tinjomoyo Tourism Forest, E3S Web of Conferences, EDP Sciences, 202, (2020)

2. Islam, L. J. Fakhri, Y. Prasetyo, B. Sudarsono, Analisis Penurunan Muka Tanah (Land Subsidence) Kota Semarang Menggunakan Citra Sentinel-1 Berdasarkan Metode DInSAR pada Perangkat Lunak SNAP, Jurnal Geodesi Undip 6, 2, (2017)

3. J. Anita, Perencanaan Kampung Bahari Sebagai Upaya Keberlanjutan, Perkampungan Nelayan Tambak Lorok, Semarang, Jurnal Arsitektur TERRACOTTA $1.3(2020)$

4. Mease, A. Lindley, A. Erickson, C. Hicks, Engagement takes a (fishing) village to manage a resource: Principles and practice of effective stakeholder engagement, Journal of environmental management, 212, 248-257 (2018)

5. Lacey, Justine, et al, Understanding and managing trust at the climate science-policy interface, Nature Climate Change, 8(1), 22-28 (2018)

6. Butler, Megan, Analyzing community forest enterprises in the Maya Biosphere Reserve using a modified capitals framework, World Development 140 (2021)

7. Gardner, John, et al, A framework for stakeholder engagement on climate adaptation, Climate Adaptation National Research Flagship Working Paper 3, 1-31 (2009)

8. A. B. Cundy, et al, Developing principles of sustainability and stakeholder engagement for "gentle" remediation approaches: The European context, Journal of Environmental Management, 129, 283-291 (2013)

9. F. Falakh, O. Setiani, Hazard Identification and Risk Assessment in Water Treatment Plant considering Environmental Health and Safety Practice, E3S Web of Conferences, EDP Sciences, 31, (2018)

10. A. Reihanian, M. N. Zalina, E. Kahrom, T. W. H. Tourism Management Perspective, 4, (2012) 